\author{
Jelena Gajić ${ }^{1}$ \\ Ivana Brdar ${ }^{2}$ \\ Radmila Živković ${ }^{2}$ \\ Tamara Ilić-Petrović
}

JEL: J11; Z10; Z13; Z19

DOI: 10.5937/industrija47-23284

UDC:379.8-053.6(497.11)"2000/..."

316.346.32-053.6(497.11)"2000/..."

Original Scientific Paper

\title{
Millennials' Perspective on Leisure Time
}

\author{
Article history: \\ Received: 23 August 2019 \\ Sent for revision: 8 September 2019 \\ Received in revised form: 28 September 2019 \\ Accepted: 28 September 2019 \\ Available online: 15 October 2019
}

\begin{abstract}
The purpose of this research is to explore leisure time of millennials in Serbia. We have put the content and structure of their 'free time' into the focus; moreover, we are interested in how far or how close young people's freely chosen activities, and relaxing and socializing patterns, are in comparison to other authors' findings, from the same region, but from other places as well. The results show that some global trends related to the topic are recognized, highly appreciated, and accepted in target population. At the same time, noticeable impact of specific cultural, social, and economic factors is relevant too so that certain local insights should be treated with respect to actual, recent, and even long-lasting local circumstances.
\end{abstract}

Keywords: leisure time, youth, millennials, activities, perspectives

\section{Slobodno vreme iz perspektive milenijalaca}

Apstrakt: Cilj istraživanja je slobodno vreme današnjih Milenijalaca u Srbiji. U fokusu rada su sadržaj i struktura odabranih aktivnosti, kao I opuštajućih $i$ društvenih obrazaca slobodnog vremena mladih ljudi, u poređenju sa nalazima drugih autora, iz regiona, ali i iz drugih zemalja. Rezultati pokazuju da su neki globalni trendovi vezani za ovu temu prepoznati, veoma cenjeni $i$ prihvaćeni u izabranoj ciljnoj populaciji. Istovremeno je uzet u obzir i značajan uticaj specifičnih kulturnih, društvenih i ekonomskih faktora, te bi određena lokalna shvatanja trebalo prepoznati i tretirati u odnosu na stvarne, nedavne $i$ čak dugotrajne lokalne okolnosti.

Ključne reči: slobodno vreme, mladi, milenijalci, aktivnosti, perspektive.

\footnotetext{
${ }^{1}$ Singidunum University, Belgrade, Serbia, igajic@singidunum.ac.rs

${ }^{2}$ Singidunum University, Belgrade, Serbia
} 
Gajić J., et al.: Millennials' Perspective on Leisure Time

\section{Introduction}

Leisure, as a form of spending time and as an integral part of everyday life, appears from the very beginning of civilization in all societies that were organized throughout human history. The meaning and importance of certain activities, time, place and way of structuring leisure, have evolved and changed from the earliest primitive communities to the modern society of today, following social change and developmental processes at all levels and in very different spheres of life.

For primitive communities it was the time of resting, but also an opportunity for expression and satisfaction of 'higher order' needs; in ancient times it became almost equalized with occupation and lifestyle - at least for the privileged, whereas for the rest it was labeled as idleness. The Renaissance celebrated leisure as extremely valuable, advanced and stimulating for creativity.

In the modern age theoreticians from different fields, from very different angles, have been dealing more rigorously with this notion, trying to determine, define, and analyze it. The content of the notion, as well as its positioning on a value scale (ethical, aesthetic, socio-psychological, socioeconomic), depends, of course, on the view point and the observer's angle starting point, discourse, and focus can be significantly different.

The basic scientific field and the particular area of interest will make the matter, purpose, and context of each investigative-analytical approach to this topic somewhat specific (Tomanović and Ignjatović, 2006). Leisure time is interesting to cultural studies, healthcare, sociologists, politicians, economists, educators, urban planners and statisticians, and service, commercial, or marketing practitioners.

\section{Literature review}

Firm, clear, and consistent conceptual framework has not taken effect: there are as many definitions as the authors who do research on leisure time (Shaw, 1984; Watkins, 2000; Schulz and Watkins, 2007; Watkins, 2010), and they are heterogeneous, covering different aspects and activities; there is neither consistency in the scientific literature nor terminological consensus inside and outside of expert community (e.g., Kelly, 1972; Iso-Ahola, 1979; Neulinger, 1981; Iso-Ahola, 1987; Tomlinson, 1989; Iso-Ahola, 1990; Rojek, 2000; Rojek, 2005; Andrews, 2006; Harris at al, 2015).

Hence Wallner and Pohler argue that leisure in a positive sense is defined as an activity of doing something, and in a negative sense as being liberated from something, such as work (Elaković, 2006). 
Dumazedier (1960) in his explanation of the notion introduces a dimension of (free) will - leisure time consists of activities that one can indulge in at one's sole discretion, one's personal choice - be it resting, having fun, socializing, relaxing, improving knowledge or skills, and only when one finishes obligations and demands that society puts before him/her. Leisure, therefore, does not pertain to work, social, or family obligations.

In a similar manner, Giddens (1964) defines this notion - as a part of life that does not imply work, going to work, or sleeping. Kelly (1972) emphasizes that leisure, besides not covering work activities, is also outside of social expectations, and it does not support survival or status of an individual.

According to the explication of Donald and Havighurst (1959), six most important meanings or functions of leisure time can be identified as: contentment (originating from the performance of favorite activities, by personal choice), contrast to work or professional activities, new experiences, social contacts, personal achievements and passage of time. Shaw (1984) similarly renders the concept of free time as a combination of following factors - enjoyment, freedom of choice, relaxation, inner motivation, and lack of evaluation of that particular (selected) activity by others.

The literature from the middle of 20th century to date indicates that, regardless of aforementioned inconsistencies and individual specificity in defining the notion of leisure, theoreticians have been more or less precisely pondering around the meanings categorized by Watkins and Bond (2007) those are activities that occupy a certain period of time, do not fall under worktime, carry in themselves certain positive feelings. The goal is for an individual to rest, relax, have fun, and fulfill a certain time-frame.

Nowadays in social sciences leisure is looked at in the context of place of occurrence, time and people present at a given moment. Moreover, contemporary interpretation of leisure also takes into account previous personal experience and culture that an individual belongs to. Kelly and Freysinger (2000) argue that it is about 'experience in a particular context, which takes a particular form, but the form itself does not define it. It takes place in a moment in time, but that particular activity determines the time, but the time does not determine the activity'. Contemporary leisure time may encompass a wide range of activities: from resting to learning new skills; from traditional activities, rituals, and entertainment to consumer behavior, sport, tourism, arts, and socializing with friends. The meaning of the notion of leisure is still complex, diverse, and in a sense, perhaps, more relative than ever complex and highly developed models of living of contemporary humans can prevent us from setting, with precision, the boundaries between work, professional, and social obligations, and 'free' activities. 
Many researchers from various fields are interested in the way people of certain communities, age, gender, occupation, and a number of other demographic and psychographic characteristics spend their leisure time (Stepanović et al, 2009). Studies have often focused on both individual and social experience of leisure time and importance that individual or collective (to whom the individual belongs) attributes to it. Furthermore, there is also great interest for the establishment of connections between the way in which leisure time is structured and 'used' and a number of personality and behavioral variables (leisure time and academic or professional performance, the influence of leisure time on personal development, characteristics, interests, etc.).

Significant place in contemporary research on this topic is occupied by studies dedicated to systematization of activities covered by leisure time (Bartko and Eccles, 2003; Bruyn and Cillessenn, 2008; Stepanovic et al, 2009).

In a sample of young people from Croatia, Ilišin (2002) examines the relationship between free time and work or academic achievement. The choice of activities affects the development of young people, their abilities, skills, knowledge and personality as a whole (Andrijašević et al, 2005).

Regardless of conceptual and methodological differences, set goals, and covered samples, the insights of contemporary researchers undoubtedly show how important free time is for contemporary humans. Relaxation, rest, enjoyment, lack of obligations and pressures, are generally considered as having great importance for an individual and a society, in all areas. As Roberts $(2006,2007,2011)$ emphasizes - leisure contributes to the general quality of life through psychological and social benefits, enabling satisfaction of a number of important needs - from activities and contacts to achievements and respect.

\section{Research methodology}

Young people are always and everywhere an interesting 'material' for researchers, theoreticians, and practitioners of very different professions, irrespective of vocational orientation and basic areas of activity. It seems even more intensely in recent years than before. In our country, the context is, in accordance with social circumstances, often negative (unsuitable behavior, unacceptable role models and values, peer violence, conservatism, lack of initiative). Interest in needs and expectations, attitudes, values, habits and preferences of young people is understandable because the survival and development of every community, in fact, depends on them. 
Conversely, precisely in the process of maturation, individuation, and socialization the role of free time is of enormous importance, even regardless of form or type of activity (e.g., socializing, going out, doing sports, as opposed to book reading or resting). It is time, actions, and behaviors that develop and express identity, communicate with environment, either independently or as they, out of their own volition, choose, decide, engage in, etc. As Melman et al. (2007) argue, there is also space for 'experiments' and 'trials' of different behaviors and approaches that young people can experience in a 'safe zone', e.g. through an activity shared with their peers.

Regardless of the ostensible extent and availability of information about the life of young people, including those related to their needs, preferences, and choices within the leisure time framework, we wanted to explore this topic in a controlled and cogent manner, and verify some of the most common, generalized beliefs that other generations have about today's youngsters. Moreover, we thought that at least some of many interesting partial insights from various sources will gain more traction in terms of quality and importance if they are subsequently revisited from the rounded, thoroughly grounded context that this study will provide.

Since we deal with a very broad, heterogeneous segment determined solely by a demographic age variable, we opted, at least in the first stage of the study, for a more focused approach. Our research is related to everyday life of Millennials. The main objective that we set out is to get to know and understand that particularly more intimate, less formal, more freely structured and, at their own discretion, organized part of their life. We were interested in the position, function, and above all the content forms with which young people here and now fulfill their leisure time.

The study is conducted in 2017 in Belgrade. It included 354 respondents: 56\% female and 44\% male Millennials. On average respondents are aged 24.

We designed the questionnaire for this study, by starting from goals, modes of investigation, specifics related to the respondents, making sure that we attain, in the most precise way possible, an authentic familiarization with the target population's relationship with the subject of our interest. Form and structure of the instrument, setup of questions, selection and formulation of offered responses were carefully designed, validated, and slightly corrected during the 'zero' pilot phase which preceded the research process. The largest number of questions was given in the format of Likert scale, while for a deeper, more in-depth insight into every area certain number of open-ended questions was asked.

The questionnaire is divided into two major sections: the generic section which covers all potentially significant demographic characteristics of 
Millennials, and the specific section which refers to attitudes, preferences, and habits of the participants regarding their utilization of leisure time.

The section of questionnaire directly related to leisure is structured so that it can cover all areas of interest and habits of young people that we recognized, either from literature or intuitively, and wanted to explore: general preferences about utilization of leisure time - sport, cultural happenings, media events, travel, and activities associated with improvement of skills and personal development.

The study is based on the data obtained by use of standard quantitative research methodology. The SPSS program was used for statistical analysis; basic results were obtained by descriptive analysis of data, while the significance of differences between groups by relevant demographic parameters was determined by analysis of variance.

\section{Results and discussion}

The respondents are much more often than expected engaged in additional, part-time jobs ( $42 \%$ of the total number). Although this is quite common for the West European countries and some other parts of the world, in the last decades in Serbia a drop in work opportunities for young people in general and youths in particular has been constantly recorded. Concurrently, the structure of these jobs has pretty much changed in comparison to the generation of their parents or older, but is closer to global trends of the late 20th and the beginning of 21st century - mostly it is a variety of promotional, marketing, sales, or service and auxiliary jobs related to food and drinks (waitering, preparation and sale of fast food, catering, delivery, etc.).

Next interesting fact is significantly more typical for the local milieu, specifically for today's socio-economic situation in Serbia, but also for the traditional models of family relations. The majority of respondents $(61 \%)$ live with their parents or other family members, in apartments of their parents, relatives, rarely rentals, and very rarely in their own. The share of those who live alone or with a partner is very small; the separation from primary and starting of their own family occurs even rarer, while shared living in a larger group of friends/peers represents the rarest model.

Monthly family income of the half of respondents is 50 to 100 thousand dinars; (27\%) has an income of less than 50000 RSD; $18 \%$ has an income between 100 and 200 thousand dinars and $6 \%$ more than 200000 dinars. When the data is compared with the general population of Serbia, we can conclude that a significant part of the sample has an income above the national average the average monthly household income in Serbia is 55,211 RSD (Statistical 
Gajić J., et al.: Millennials' Perspective on Leisure Time

Office of the Republic of Serbia, 080-god.LXVI, 31.03.2016. www.webrzs.stat.gov.rs).

Familiarization with habits, affinities, content forms that attract young people and shape their leisure started with self-assessment of importance and interestedness in some activities.

The table indicates percentage of respondents who assessed that they are 'very interested' in spending time in such manner. Respondents independently evaluated each of the activities listed below.

Table 1. Activities in which respondents engage in their leisure time

\begin{tabular}{|l|l|l|}
\hline & $\begin{array}{l}\text { Percent of respondents } \\
\text { interested in spending their } \\
\text { time in manners listed below }\end{array}$ & $\begin{array}{l}\text { Average grade of preference of } \\
\text { each activity } \\
\text { (from 1 to 5) }\end{array}$ \\
\hline Time with friends & 56.6 & 4.40 \\
\hline Internet & 31.4 & 3.92 \\
\hline Time in the nature & 29.9 & 3.65 \\
\hline Books & 28.2 & 3.58 \\
\hline Sport & 25.7 & 3.40 \\
\hline Radio & 14.7 & 2.88 \\
\hline Theater & 14.4 & 2.87 \\
\hline Movie theater & 8.2 & 2.78 \\
\hline Magazines & 7.3 & 2.74 \\
\hline Television & 4.8 & 2.54 \\
\hline
\end{tabular}

When not busy with their every-day activities (work, attending lectures, etc.), respondents preferably and most often are in the company of their peers. To a substantial degree they turn to outdoor activities, in the open, regardless of whether it is sport, recreation, walking, or just being outside with some of their friends. At home, or in public places, in transportation or parks, the Internet is their very important everyday companion.

Regarding 'traditional media', it seems that there still exists interest and certain attachment to the radio; TV is significantly less often mentioned as important and deliberately chosen activity and the press too. However, we will see below how objective and factual is noticeably moved away from acceptable and desirable - thus, e.g., in everyday life of young people time spent in front of TV significantly exceeds that allocated to reading or visiting cultural events.

This finding, along with the fact that the movie theater has lost the importance it had in the region in previous generations, can be explained by recognition of the Internet as a unique place/manner for the satisfaction of 'unified' individual needs - information, communication, culture, entertainment, etc. The book, however, regardless of its content, genre or function, still remains esteemed, attractive, and important for student population (Rajić et al, 2019), in its 'old- 
fashioned' printed format to boot.To what degree young people really choose to dedicate their free time to the book, certainly if it is not related to the regular coursework requirements, then it is the question with a slightly different response, the answer to which we'll try to obtain in the text below.

Activities that attract and preoccupy young people to some extent depend on their gender. Analysis of variance of the average grade of each listed activity, on scale from 1 to 5 shows us where the differences are most striking:

Table 2. Results of analysis of variance: arithmetic mean, $F$ statistics, degrees of freedom and statistical significance

\begin{tabular}{|l|l|l|l|l|l|}
\hline \multirow{2}{*}{$\begin{array}{l}\text { Type } \\
\text { program }\end{array}$} & Average grade & F & df & P \\
\cline { 2 - 3 } & Women & Men & & & \\
\hline TV & 2.67 & 2.38 & 5.7 & 353 & .017 \\
\hline Books & 3.85 & 3.25 & 22.06 & 353 & .000 \\
\hline Movie theater & 2.99 & 2.5 & 15.178 & 353 & .000 \\
\hline Theater & 3.15 & 2.52 & 22.473 & 353 & .000 \\
\hline Internet & 3.82 & 4.05 & 5.291 & 353 & .022 \\
\hline Sport & 3.18 & 3.7 & 14.547 & 353 & .000 \\
\hline
\end{tabular}

On average, female part of the sample shows significantly higher interest in cultural contents and events (theater, movies, literary arts), but simultaneously we can also recognize a tendency to somewhat more passive, slower, and even more traditional manner of spending leisure time (watching TV, bookreading, going to movies or theatrical performances represent not only the most frequent women's choices, but also the greatest sources of pleasure, relaxation, and fulfillment).

Male respondents generally select less activities, yet they show very high involvement in their choices; both of these aspects make sport and the Internet more typical for male daily rhythm, for the area of special interest and the cornerstone of communality.

A series of subtle distinctions and gender specifics will be discussed later, during the analysis of certain activities that are significant for Millennials of both genders; what appears to be a universal value and what certainly significantly determines the structure, organization, quality, and content of leisure time is the social factor - presence or participation of a close circle of friends.

Significant gender differences regarding leisure time and content forms that fill it up were also observed in Turkey. According to the research results, the male part of respondents shows stronger preferences for sport and tourism, while the female population more often opt for cultural and artistic happenings. The data also suggest a possible influence of traditional social expectations - girls have fewer opportunities for leisure activities or are less 
encouraged to actively participate in them. On average, they spend more time at home, and despite the fact that they find free time important, they more often than their fellow male report that they do not have enough of it (Karaca et al, 2009).

Influence of traditional social expectations is identified also in the behavior of girls and young women in Bulgaria (Mitev and Kovachev, 2014). Although preferences towards some of the extracurricular activities are equally expressed, they are still expected to spend more time at home, e.g., reading books, and to be interested in artistic and cultural content, more than in sports and the like. Conversely, the data show that behavior of the male counterparts implies, among other things, sport activities, going out with friends, alcohol consumption, physical strength and aggressiveness.

\subsection{Leisure Time - Structure and Content of Daily Activities}

Television has definitely lost its importance for the surveyed generation, primarily under the influence of the new, interesting, and, to the young people closer, media. The fact is, however, that almost every day a certain time period is spent in front of or around television program. At first glance arguments are different but actually point to the common cause - serious financial and time pressures easily direct attention to the most accessible and ubiquitous media programs, no matter how low they are valued! Traditionally centrally placed in the family setting, the TV also provides a possibility to realize with a minimal effort and investment (financial, intellectual, and emotional) a series of models of behavior, from rest and pleasure in the dedication to personal choice, to sharing and exchange with the close circle, of family members and friends.

Attitude towards content and type of program is largely linked to individual affinities, but in such way that regularities very clearly follow gender variable. Sport is a very suitable example - extremely polarized position: a fifth of the respondents demonstrate the highest level of interest for correlating TV shows, a fifth is not interested at all and does not follow content forms from the field of sport. There are significantly more 'passionate fans' in the male segment of the sample.

Political programs are positioned according to a very similar model, whereas entertainment, education, and newscast programs are slightly less dependent on gender and are familiar to some degree to the majority of study participants. News about culture, entertainment formats, and service information, especially if they are 'apportioned', linked, and presented as a whole (for example, morning program), are extremely attractive to one part of the female surveyed population. 
Gajić J., et al.: Millennials' Perspective on Leisure Time

Table 3. Results of analysis of variance: arithmetic mean, F statistics, degree of freedom and statistical significance

\begin{tabular}{|l|l|l|l|l|l|}
\hline \multirow{2}{*}{ Type of program } & Average grade & F & Df & P \\
\cline { 2 - 3 } & women & men & & & \\
\hline Cultural & 3.35 & 3.01 & 7.464 & 325 & .007 \\
\hline Entertainment & 3.35 & 2.97 & 14.535 & 326 & .000 \\
\hline Morning & 2.82 & 2.36 & 9.506 & 320 & .002 \\
\hline Sport & 2.41 & 3.54 & 50.948 & 317 & .000 \\
\hline Politics & 1.91 & 2.2 & 4.091 & 317 & .044 \\
\hline
\end{tabular}

According to the research findings in Croatia (llišin et al, 2013), young people most often opt for programs that are relaxing and brief-and-informative, so the most watched programs are comedies (48\%) and other TV series (46\%), news $(42 \%)$, whereas religious and political programs and Croatian folk music $(2 \%, 6 \%, 10 \%)$ take the last position.

The research from 2014 on frequency of television program viewings in 24 countries of the EU, which included a variety of social and professional categories, shows that: $88 \%$ of respondents spend time in front of TV at least once a week, $70 \%$ almost every day, $18 \%$ once or two-three times a week, $7 \%$ two or three times a month, while 5\% reports never watching TV programs. (The Statistics Portal)

Andò et al. (2016) conducted a research focusing on the consumption of television as a medium among Italian and American youth. The results show that the majority in both countries watch TV about 1-3 hours a day. At home, usually in the company of family or friends, while with the change of environment they opt for independent viewing of programs, and on the alternative devices (computer, tablet) to boot. A noticeable difference is that the viewership in Italy watches traditional TV program, in contrast to the Internet (Streaming) TV that is very popular in the USA.

Daily newspapers are part of everyday life for the largest part of the sample we surveyed - even $86 \%$ of respondents maintain that 'browsing daily newscast' is their usual habit, more often electronic format, but depending on circumstances (availability) - print format too. About half of the participants consider themselves regular or occasional readers of magazines, of different content and thematic orientation. Preferences in this domain follow general inclinations and interests; thus, sport appears to have more significant share in comparison to other topics.

Gender differences consistently follow and further illuminate already described typical models of leisure time spending. In accordance with our expectations, girls are increasingly more interested in arts, health, fashion, cosmetics and life of celebrities, whereas men prefer information about sports, car racing, and politics. 
Gajić J., et al.: Millennials' Perspective on Leisure Time

Table 4. Results of analysis of variance: arithmetic mean, F statistics, degrees of freedom and statistical significance

\begin{tabular}{|l|l|l|l|l|l|}
\hline Domain & $\begin{array}{l}\text { Women } \\
\text { (average } \\
\text { grade) }\end{array}$ & $\begin{array}{l}\text { Men } \\
\text { (average } \\
\text { grade) }\end{array}$ & $\mathrm{F}$ & $\mathrm{Df}$ & $\mathrm{p}$ \\
\hline Arts & 3.28 & 2.77 & 15.976 & 301 & .000 \\
\hline Health & 3.27 & 2.88 & 7.922 & 298 & .005 \\
\hline Fashion & 3.42 & 2.03 & 96.065 & 300 & .000 \\
\hline Celebrities & 2.47 & 1.99 & 11.703 & 294 & .001 \\
\hline Cosmetics & 3.52 & 1.73 & 169.283 & 300 & .000 \\
\hline Car racing & 2.15 & 3.05 & 35.473 & 297 & .000 \\
\hline Politics & 2.59 & 3.00 & 6.781 & 301 & .010 \\
\hline Sport & 2.58 & 3.51 & 31.491 & 297 & .000 \\
\hline
\end{tabular}

Among American Millennials, the structure of 'recreational' reading by content or type of publication is shown in the results of the research carried out by Braguglia (2005). On a daily basis, $25 \%$ of respondents read magazines, $22 \%$ Internet publications, $20 \%$ religious content, $18 \%$ various daily newspapers.

For most of the participants books are not part of a daily rhythm or an authentic choice of leisure activity. The majority does not read regularly, and the most usual 'justification' refers to a lack of (free) time - this, along with other arguments, points out to the fact that the book is more perceived as useful, smart, and a source of information, knowledge, general culture, etc., but very rarely as a strong internal need and a firmly established habit that provides an enjoyment in itself. Most respondents read from one to several books a year, apart from mandatory or additional literature related to academic goals. Among the book reading fans (around a third of the sample) there appear to be three approaches, relatively equal by frequency of occurrence, which can be formulated as: I read to absorb as much as possible (generally, about everything) / I read to learn as much as possible (from one particular field or more, because I am interested in it) / I read because I love it (I have always been reading and cannot live without reading).

Books and newspapers are the least represented content in young people's leisure time in Croatia and this trend has been steadily going down over the last thirty years (llišin et al, 2013). When we look at the trends among the US young people, Braguglia (2005) reports that book reading is a part of their daily or weekly routine for less than half of the respondents, regardless of whether they opt for novels, nonfiction, fiction, poetry or comics. Others, a little more than half of the sample, read some title out of the mentioned literary genres once a year or never.

Playing sport, primarily in the form of recreation, is an important segment of our respondents' free time. Interest in sport events, following sports newscast and gathering on 'sport motivated' occasions are typical of the male respondents. Personal preferences are grouped largely around different forms 
of aerobics/dance for girls and basketball/football for men, whereas swimming, tennis, and gym appear as choices regardless of gender.

The data from already mentioned studies show a very similar position of sport among young people in Croatia, Bulgaria, Serbia, the UK, and Ireland (Tomanović and Ignjatović, 2006; Tomanović et al, 2012; Ilišin et al, 2013; Mitev and Kovachev, 2014; Sodexo University Lifestyle Survey, 2014; Tomanović and Stanojević, 2015). Around a third of surveyed young people are active in some form of sport activity, albeit in varying intensity on a daily or weekly basis.

Movie theaters, concerts, and exhibitions, on average, are attended very rarely. Less than $10 \%$ of respondents regularly (several times a month) go to the movies, while less than $5 \%$ of respondents equally often enjoy other types of cultural happenings. Gender differences were most pronounced when it comes to theater, where girls are more active $(M=2.52$ vs. $M=2.34$, $F(318)=10.579, p=.001)$.

Very similar findings, even somewhat lower percentage of visits to the movies, drama performances, and museums, are reported in the survey from Bulgaria (Mitev and Kovachev, 2014).

In contrast to daily activities that require less planning, organization, and significantly less disposable financial assets, when it comes to travel, striking individual differences come to the fore. The scope of responses related to touristic habits ranges from: I never travel (2\%), I travel once in two-three years (about $10 \%$ ), I travel once or twice a year (about 50\%), etc., to those who do that significantly more often (slightly less than $30 \%$ of the participants reports that they travel several times every year). To the largest number of respondents a sea trip is a number one choice and a favorite destination, followed by the famous cities (European and world metropolises) and mountain resorts. Young people express very high interest in exotic landscapes (faraway islands, safari, deserts, etc.) and less conventional tourist tours (e.g., cruises), while on the 'wish list' (either previous experiences, or future plans) significantly less likely are lakes, villages, and spa resorts.

For over $90 \%$ of respondents the Internet is irreplaceable and must-have everyday companion. To get in contact with this medium, according to their own opinion, Millennials are steered by not only professional, but also personal reasons and needs; they report that they spend between 4 and 7 hours a day on the Internet. The most popular Internet functions are: e-mail checking, browsing, using social networks, and downloading. Furthermore, the Internet also represents an important source of information about products and services. Facebook and YouTube are listed as by far the most popular sites. Somewhat less often respondents visit Blic and B92 sites and Twitter. 
The genders are equal when it comes to the Internet activities, and the only noticeable difference refers to the higher interest of men to maintain their websites than girls ( $M=2.18$ vs. $M=2.51, F(314)=5.523, p=.019)$.

A series of surveys in recent years from many countries point to global trends regarding the relationship of the young people with the Internet. Our sample in this segment of their behavior and the manner of utilizing their leisure time perhaps resemble at the most their fellows; similarity can be found in the time dedicated to the Internet activities, the preferred features or amenities, and the importance they attach to the daily consumption (Stanojević, 2012; llišin et al, 2013; Monahan et al, 2013; Mitev and Kovachev, 2014; Sodexo University Lifestyle Survey, 2014; Poscia et al, 2015).

Among the preferred activities, pointed out by the afore-mentioned findings and many other published research studies, there are some that are not (yet) to any significant extent a part of the daily life within our sample. Thus, in the surveyed population a pronounced and direct connection between the Internet and learning, regular observation of academic content, and participation in the process of college studies has not been manifested. On-line purchases and payments are also slightly less represented activities in relation to the findings of studies, primarily, of the West European and American colleagues. Communication, information, and entertainment are the most important functions and motives for choosing the Internet as a favorite aspect of leisure activities of our respondents.

More than half of respondents (56\%) in the last two years have attended some seminar, course, or training, which shows that in this segment of the population leisure time is to a great degree dedicated to additional education and upgrade of knowledge and skills.

Foreign language courses (19.8\%) of respondents attended a course of this type) are the most popular, but there seems to be a number of other very different areas. It is interesting that a fraction of respondents (6.8\%) opted to work on themselves through the development of communication skills, which is a relatively new field offered in our market.

\section{Conclusion}

Findings of the study, some of the most interesting ones are presented in this paper, indicate possible interpretations in several directions, or at several different levels.

'Globality', universality or similarity of behavior and preferences of our surveyed population with those characteristics of their counterparts, peers from very different backgrounds, certainly represent very important data. The 
importance that our respondents attribute to their own leisure time, but also to the structure of activities and choice of the content forms that fill their leisure time are apparently to a high degree typical for the generation and the segment of population to whom they belong, at least regarding neighboring and European countries and the USA. At the age of dominance of global communications and extremely fast exchange of information, it seems that local 'obstacles' (primarily aggravating social and economic circumstances, foreign politics constraints, as well as cultural and historical specificities) have not decisively influenced, caused, or encouraged isolation toward more general generational trends.

The Internet is not only the favorite activity in our sample, but obviously also the mode, means, and path that enables and simultaneously explains the global influences and confirmed similarities.

Conversely, some of the findings show, as expected, that local values and cultural influences can be identified among the surveyed population too. Exceptional dedication to sharing, communality, companionship, communication and spending time with the favorite people - can be also 'read' in both the immediate results and through interpretations and insights in other, independent variables.

Heightened traditionalism and conservativism, according to findings of numerous studies specific to the societies in our region, may be in some degree associated with the noted gender differences. As described by our colleagues who researched free activities of Turkish and Bulgarian young people, different expectations but also different stimuli affect the formation of habits and behavior orientation of girls and boys, even when it comes to the most personal choices and the least controlled time.

Finally, we should also mention the finding that we would like to compare with those obtained by colleagues from other regions, researching the same phenomenon in the same target population. Although we deliberately have not dealt with personal attitudes but with more direct behavior (habits, activities, happenings), the line of the differentiation of the desired (personal highly valued, socially acceptable, desirable) in contrast to the factual could have consistently been followed. Hence, the book is more appreciated than read, whereas with the TV situation is opposite. It is interesting that deviations are not equal in all content forms - the highest are in the above mentioned, whereas the smallest are in sports and the Internet.

Limitations of the study, namely the obtained results, could be partially ascribed to the covered sample. Meanwhile, it represents a strong motive for continuing research on the subject matter of our interest. Besides expansion of the sample that would give us an opportunity for more general inferences, subtler analyses, and comparisons, in the next stage we could definitely apply 
some of the advanced techniques of qualitative methodological approach, with the aim of deeper understanding of the always current phenomena.

\section{References}

Andò, R., Pizza, S., \& Corsini, F. (2016). Watching television today. A comparative survey of Italian and American students' habits in front of television. Journal of Italian Cinema and Media Studies, 4(2), 283-306. doi:10.1386/jicms.4.2.283_1

Andrews, D. (2006). Leisure Studies: Progress, Phases and Possibilities - An Interview with Alan Tomlinson. Leisure Studies, 25(3), 257-273. doi:10.1080/02614360600746889

Andrijašević, M., Paušić, J., Bavčević, T., \& Ciliga, D. (2005). Participation in leisure activities and self-perception of health in the students of the University of Split. Kinesiology, 37 (1):21-31. Retrieved from: http://hrcak.srce.hr/4135.

Bartko, W.T., \& Eccles, J.S. (2003). Adolescent Participation in Structured and Unstructured Activities: A Person-Oriented Analysis. Journal of Youth and Adolescence, 32(4), 233-241. doi:10.1023/a:1023056425648

Braguglia, K.H. (2005). Reading Habits Of Business Students. Journal of College Teaching and Learning (TLC), 2(3), doi:10.19030/tlc.v2i3.1788

de Bruyn, E.H., \& Cillessen, A.H.N. (2008). Leisure Activity Preferences and Perceived Popularity in Early Adolescence. Journal of Leisure Research, 0(3): 442-457. Retrieved https://www.researchgate.net/profile/Eddy_De_Bruyn/publication/254 ....

Donald, M.N., \& Havighurst, R.J. (1959). The Meanings of Leisure. Social Forces, 37(4), 355-360. doi:10.2307/2574185

Dumazedier, J. (1960). Current problems of the sociology of leisure. International Social Science Journal, 4(4): 522-531. Retrieved from: http://unesdoc.unesco.org/images/0001/000168/016832eo.pdf.

Elaković, S. (2006). Sociologija slobodnog vremena i turizam. Beograd: Ekonomski fakultet.

Giddens, A. (1964). Notes on the Concepts of Play and Leisure. The Sociological Review, 12(1), 73-89. doi:10.1111/j.1467-954x.1964.tb01247.x

Harris, D. (2015). Threshold concepts in teaching Leisure Studies. Leisure Studies, 36(2), 282-292. doi:10.1080/02614367.2015.1052837

Ilišin, V., Bouillet, D., Gvozdanović, A., \& Potočnik, D. (2013). Mladi u vremenu krize. Zagreb: Institut za društvena istraživanja u Zagrebu.

Ilišin, V. (2002). Interesi i slobodno vrijeme mladih. In V. Ilišin \& F. Radin (Eds.), Mladi uoči trećeg milenija. Zagreb: Institut za društvena istraživanja; Ljubljana: Ministry of Education and Sports Office of the Republic of Slovenia for Youth; Maribor: Aristej. 269-301.

Iso-Ahola, S.E., \& Weissinger, E. (1987). Leisure and Boredom. Journal of Social and Clinical Psychology, 5(3), 356-364. doi:10.1521/jscp.1987.5.3.356

Iso-Ahola, S.E., \& Weissinger, E. (1990). Perceptions of Boredom in Leisure: Conceptualization, Reliability and Validity of the Leisure Boredom Scale. Journal of Leisure Research, 22(1), 1-17. doi:10.1080/00222216.1990.11969811

Iso-Ahola, S.E. (1979). Basic Dimensions of Definitions of Leisure. Journal of Leisure Research, 11(1), 28-39. doi:10.1080/00222216.1979.11969373 
Gajić J., et al.: Millennials' Perspective on Leisure Time

Karaca, A., Caglar, E., \& Cinemre, Ş. (2009). Physical Activity Levels of the Young Adults in an Economically Developing Country: The Turkish Sample. Journal of Human Kinetics, 22(1), doi:10.2478/v10078-009-0028-z

Kelly, J.R. (1972). Work and leisure: a simplified paradigm. Journal of Leisure, 4.1: 50. Retrieved

from: http://search.proquest.com/openview/2aa24d7b059a0a6225b4b04cef833a80/1? pq-origsite $=$ gscholar $\& \mathrm{cbl}=1816610$.

Kelly, J.R., \& Freysinger, V. (2000). 21st century leisure: Current issues. Needham Heights, MA: Allyn and Bacon.

Mitev, P.E., \& Kovachev, S. (2014). Young People in European Bulgaria, A Sociological Portrait 2014. Bulgaria: Friedrich Ebert Foundation.

Monahan, M., Shah, A., \& Turnes, P.B. (2013). The internet habits of university students in Spain and the USA. Journal of International Business and Cultural Studies, Vol. 7. Retrieved from http://www.aabri.com/manuscripts/121155.pdf.

Neulinger, J. (1981). To leisure: An introduction. Boston: Allyn and Bacon Research.

Poscia, , Friscale, A., Parente, E.M., la Milia, P.D.I., Waure, C., \& Di, P.M.L. (2015). Study habits and technology use in Italian university students. Ann Ist Super Sanità, 51(2); 126-130; DOI: 10.4415/ANN_15_02_10..

Roberts, K. (2006). Leisure in Contemporary Society. UK: CABI Publishing.

Roberts, K. (2007). Youth Transitions and Generations: A Response to Wyn and Woodman. Journal of Youth Studies, 10(2), 263-269. doi: $10.1080 / 13676260701204360$

Roberts, K. (2011). Leisure: the importance of being inconsequential. Leisure Studies, 30(1), 5-20. doi:10.1080/02614367.2010.506650

Rojek, C. (2000). Leisure and the rich today: Veblen's thesis after a century. Leisure Studies, 19(1), 1-15. doi:10.1080/026143600374806

Rojek, C. (2005). An outline of the action approach to leisure studies. Leisure Studies, 24(1), 13-25. doi:10.1080/0201436042000250159

Schulz, J., \& Watkins, M. (2007). The Development of the Leisure Meanings Inventory. Journal of Leisure Research, 39(3), 477-497. doi:10.1080/00222216.2007.11950118

Shaw, S.M. (1984). The meaning of leisure in everyday life. Leisure Sciences, 7(1), 124. doi:10.1080/01490408509512105

Sodexo University Lifestyle Survey, Sodexo, in association with Time Higher Education. (2014). London. Accessed on January 2016. Retrieved from http://avanconspourluniversite.sodexo.fr/documents/student-survey-uk.pdf.

-Statistical Office of the Republic of Serbia (SORS). (2014). Statisitical Yearbook of the Republic of Serbia - Education. Accessed on February 2015, retrieved from http://webrzs.stat.gov.rs/WebSite/repository/documents/00/01/54/02/05Obrazovanje.pdf.

Stanojević, D. (2012). Media use among young people in Serbia. Sociologija, 54(2), 369-385. doi:10.2298/soc1202369s

Stepanovic, I., Videnovic, M., \& Plut, D. (2009). Obrasci ponašanja mladih tokom slobodnog vremena / Youth spare time: Typical patterns of behavior. Sociologija, 51(3), 247-261. doi:10.2298/soc0903247s

Rajić, T., Nikolić, I., \& Milošević, I. (2019). Integrativni model kvaliteta odnosa sa korisnicima u oblasti visokog obrazovanja - istrazivanje u Srbiji. Industrija, 47(2), 43-59. doi:10.5937/industrija47-22044 
Gajić J., et al.: Millennials' Perspective on Leisure Time

-The Statistics Portal. . Retrived from http://www.statista.com/statistics/452452/europe-tv-usage-frequency-by-socioprofessional-category/.

Tomanović, , Stanojević, S., Jarić, D., Mojić, I., Dragišić, D., Labaš, S., . . Živadinović, I. (2012). Mladi - naša sadašnjost: Istraživanje socijalnih biografija mladih u Srbiji. Belgrade: Čigoja Press; Belgrade: Faculty of Philosophy - Institute for Sociological Research.

Tomanović, S., \& Ignjatović, S. (2006). The Transition of Young People in a Transitional Society: The Case of Serbia. Journal of Youth Studies, 9(3), 269285. doi:10.1080/13676260600805648

Tomanović, S., \& Stanojević, D. (2015). Mladi u Srbiji 2015. Stanja, opažanja, verovanja i nadanja. Beograd: Friedrich Ebert Stiftung.

Tomanović, S., \& Ignjatović, S. (2006). Attitudes on transition to adulthood among young people in Serbia. Sociologija, 48(1), 55-72. doi:10.2298/soc0601055t

Tomlinson, A. (1989). Whose side are they on? Leisure studies and cultural studies in Britain. Leisure Studies, 8(2), 97-106. doi:10.1080/02614368900390101

Watkins, M.N. (2010). A longitudinal study of changeability in leisure meanings. Leisure Studies, 29(4), 361-376. doi:10.1080/02614367.2010.518622

Watkins, M. (2000). Ways of Learning about Leisure Meanings. Leisure Sciences, 22(2), 93-107. doi:10.1080/014904000272876

Watkins, M., \& Bond, C. (2007). Ways of Experiencing Leisure. Leisure Sciences, 29(3), 287-307. doi:10.1080/01490400701259985 